\title{
EU sets new rates for young researchers...
}

Munich. The European Commission last week agreed new rules for assessing the value of fellowships awarded to young scientists under its Training and Mobility of Researchers (TMR) programme. The agreement, designed to bring awards more closely in line with local pay scales, comes just in time for the distribution of the first round of grants under the fourth Framework Programme, worth ECU41.4 million (US\$54.6 million), approved in September.

Until now, the commission has provided a fixed sum to support young scientists from each European Union (EU) country undertaking research for up to two years in another member state. But different taxation rules and demands for accompanying overhead payments from host institutions have meant that the amount passed to researchers varied significantly between countries, and have often been grossly out of line with local salaries. In Germany, for example, a grantholder often ended up being paid as much as the head of the department he or she was working in (see Nature 361, 196; 1993).

Recognizing the problems that this

\section{and continues funding for INTAS}

Munich. European Union (EU) research ministers last week agreed to give the European Commission in Brussels greater control over the operations of INTAS, the intergovernmental organization that channels European money to basic scientists in countries of the former Soviet Union.

In return, the ministers agreed that the commission should

provide sufficient support to allow INTAS to continue to operate for a further four years, and that it should remain an independent body, rather than being incorporated into the EU's

general research Cresson: commission programme for cen- will continue funding. tral and eastern Europe.

INTAS was established in 1993, on the initiative of the former French president, François Mitterrand, by the European Commission and the 15 current EU member states, plus Norway and Switzerland. Its goal is to help to support scientists in what are known collectively as the new independent states (NIS) of the former Soviet Union.

But its future had been put in doubt by criticism from parts of the scientific community, subsequently taken up by the new research commissioner, Edith Cresson, of the way its internal administrative procedures led to long delays before funding for approved projects reached the NIS scientists concerned (see Nature 374, 203; 1995).

This, in turn, had fanned discontent among member states. Most of the ECU53 million (US\$70 million) that INTAS has so far received has come from the commission's research budget. But ECU3 million has been provided by individual member states which are no longer so keen to provide additional funds

Faced with the likelihood of becoming the sole contributor, the commission has considered dissolving INTAS and distribut- ing the funds available for scientific cooperation with NIS through its existing international cooperation (INCO) scheme.

INCO has an annual budget of ECU60 million for research projects in central and eastern European countries and the NIS, although the commission has yet to agree how this sum should be divided between the two groups. But some member states opposed the plan to merge it with INTAS. As a result, the council of ministers has agreed that, in exchange for giving the commission more strategic control over its activities, INTAS should continue its independent existence, receiving half of the research funds allocated by the commission for research projects in the NIS (the other half will go on applied research projects).

Under the new terms, the commission will chair the INTAS assembly - the body that sets its general policy - and will be able to veto all its decisions. "This will ensure that we can promote synergy with other commission research programmes," says Rainer Gerold, a spokesman for the INCO programme.

The research ministers called for additional measures to make INTAS more efficient - including a reduction in the number of administrative staff at its headquarters in Brussels. They also called for individual member states to continue additional funding, and for research organizations of the NIS to increase their own contribution. This year, for example, Kazahkstan, Russia and the Ukraine jointly contributed ECU3.7 million to research projects carried out with scientists in Western Europe.

The commission will decide over the next few weeks how its total budget for supporting research in central and eastern Europe and the NIS is to be divided. Just over half is likely to go to central European countries, including Poland, the Czech Republic and Hungary, in recognition of their interest in EU membership. If this happens, INTAS will receive around ECU13 million a year over the remaining three years of the Framework programme.

A.A. caused, the EU council of ministers agreed last year to seek a mechanism to ensure that all TMR grant-holders receive the same net income as a national researcher at the same professional level. The commission has now approved rates for studentships and fellowships submitted by each member country that achieve this goal.

In most countries, awards will take the form of a taxable work contract, rather than a bursary. The net payment made by the commission will vary between about ECU900 and ECU1,500 a month for a studentship, and about ECU1,300 to ECU2,000 for a fellowship, depending on the host country. A single flat rate of ECU10,000 a year in overheads will be paid in each member state.

This system for distributing awards will be adopted as a model by all other EU research programmes. But, although more equitable than the previous system, it has its price. Under the new rules, TMR fellowships are more expensive, and the total number of grants that can be offered has therefore fallen by several hundred. But the commission still hopes to award up to 4,000 training grants with the ECU260 million it has to distribute over the next four years.

The commission also agreed last week that two-thirds of the total will be allocated as postdoctoral fellowships. Only 20 per cent will be given as studentships, in line with the commission's policy that graduate education should be a national, rather than a European, concern. Ten per cent of the money will be given to grant-holders returning to 'less privileged' regions of the EU, such as Merseyside in the United Kingdom, eastern Germany and some Mediterranean countries, on condition that they continue their research for up to a year.

Despite the much criticized bureaucracy of the mobility programme, its popularity continues to grow. More than 2,200 projects were submitted in the first call for proposals in summer, of which 513 are to be funded. While the success rate for fellowship applications was 28 per cent, the commission received significantly more applications for $\mathrm{PhD}$ grants than it had expected, pushing the acceptance rate to below 10 per cent.

Oversubscription has also caused a problem in the part of the TMR programme that funds research networks. Only 6.4 per cent of the proposals submitted earlier this year for the first call, involving the distribution of ECU150 million, could be accepted.

"We are not able to fund excellent projects, only outstanding ones, and we are very disturbed to see top-graded applications being turned down", Jürgen Rosenbaum, a spokesman for the TMR programme, told a meeting of German university administrators held in Regensburg last month.

Alison Abbott 